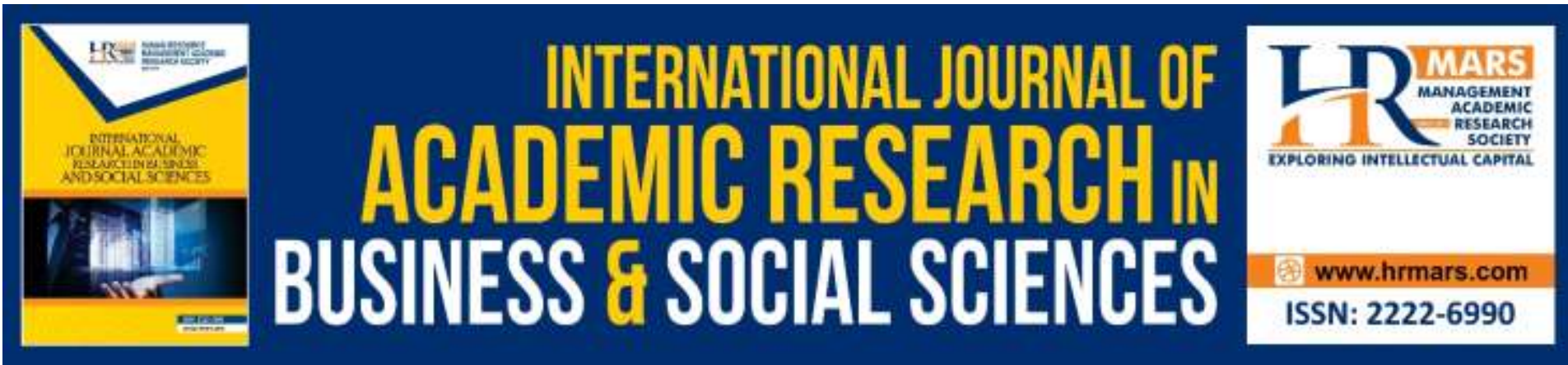

\title{
Investigating the Effectiveness of Inter-Varsity Stock Challenge to Inculcate Stock Trading Literacy Amongst Youth
}

Lim You Ping, Loh Kah Heng, Theresa Chiew Gim Ean and Ong Jing Kai

To Link this Article: http://dx.doi.org/10.6007/IJARBSS/v10-i5/7176 DOI:10.6007/IJARBSS/v10-i5/7176

Received: 01 March 2020, Revised: 02 April 2020, Accepted: 27 April 2020

Published Online: 04 May 2020

In-Text Citation: (Ping et al., 2020)

To Cite this Article: Ping, L. Y., Heng, L. K., Ean, T. C. G., \& Kai, O. J. (2020). Investigating the Effectiveness of Inter-Varsity Stock Challenge to Inculcate Stock Trading Literacy Amongst Youth. International Journal of Academic Research in Business and Social Sciences, 10(5), 86-101.

Copyright: (C) 2020 The Author(s)

Published by Human Resource Management Academic Research Society (www.hrmars.com) This article is published under the Creative Commons Attribution (CC BY 4.0) license. Anyone may reproduce, distribute, translate and create derivative works of this article (for both commercial and non-commercial purposes), subject to full attribution to the original publication and authors. The full terms of this license may be seen at: http://creativecommons.org/licences/by/4.0/legalcode

Vol. 10, No. 5, 2020, Pg. 86 - 101

Full Terms \& Conditions of access and use can be found at http://hrmars.com/index.php/pages/detail/publication-ethics 


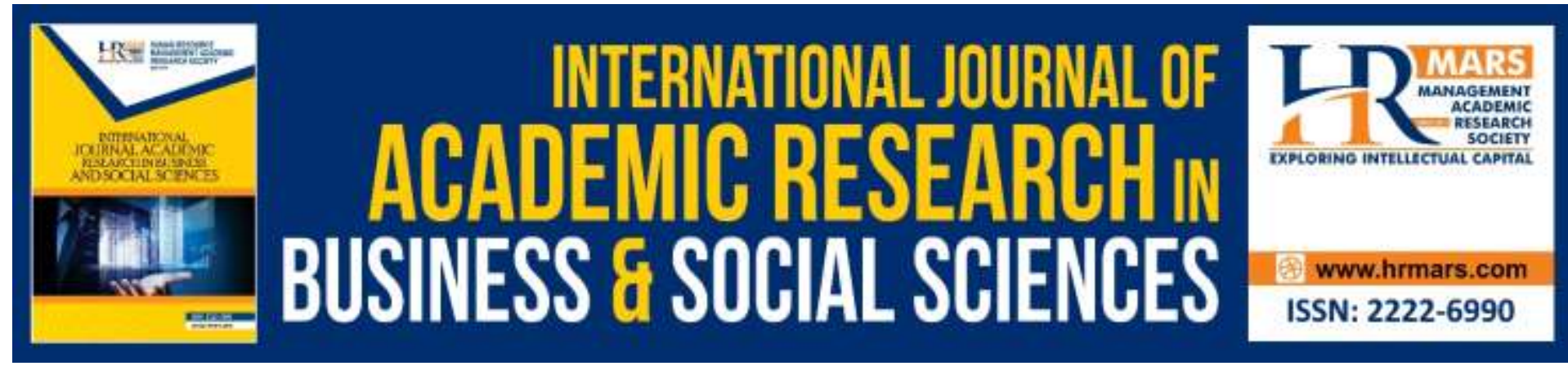

\title{
Investigating the Effectiveness of Inter-Varsity Stock Challenge to Inculcate Stock Trading Literacy Amongst Youth
}

\author{
${ }^{1}$ Lim You Ping, ${ }^{1}$ Loh Kah Heng, ${ }^{1}$ Theresa Chiew Gim Ean and \\ ${ }^{2}$ Ong Jing Kai \\ ${ }^{1}$ School of Liberal Arts and Sciences, Faculty of Social Science and Leisure Management, \\ Taylor's University, Malaysia, ${ }^{2}$ Department of Risk and Insurance, Wisconsin School of \\ Business, University of Wisconsin-Madison, USA
}

\begin{abstract}
Experiential learning through educational simulation provides opportunity for development of hard and soft skills requested by employers. The acquired skills prepare learners for future employment through ability of application of theories and concepts in real-life situations. This paper describes the Inter-Varsity Stock Challenge (IVSC) as an example of experiential learning through stock trading simulation in increasing investment awareness to promote stock trading literacy amongst millennials who are the next generation of investors. This stock trading competition allowed participants to learn and practice in a risk-free environment, thus, providing an avenue to nurture their interest and develop their talent in stock trading. We believe that this approach of learning will enable participants to bridge the gap between theoretical concepts and real-life financial investment decision. This study adapts George Miller framework for assessing levels of competency by including the level of awareness prior to the simulation of stock trading. The learning experience of participants before and after participating in the stock trading simulation competition were captured in a 32 items online questionnaire consisting of cognitive, affective and physical dimensions through a 5-point Likert scale questionnaire. A reliability analysis on the perceived task values scale with Cronbach's alpha between 0.71 and 0.96 indicates that the measures were valid as the reliability coefficients obtained for all 3 dimensions were higher than the recommended level of 0.70 . The collected data was analyzed using statistical package, SPSS 20. The statistical results revealed that the IVSC has met its objective to raise stock trading literacy amongst the youth. Business major participants have gained relatively higher stock trading literacy as compared to non-business major participants after participating the IVSC. The results also affirmed that the stock trading workshops series has effectively enhanced the stock trading literacy of participants. However, there were no significant difference between gender of participants in enhancing their stock trading literacy. This indicated that all participants regardless of gender have learnt about stock trading throughout the IVSC as an example of experiential learning through stock trading simulation in increasing investment awareness and stock trading literacy in the equity market. Keywords: Experiential Learning, Stock Trading Simulation, Stock Trading Literacy, InterVarsity Stock Challenge (IVSC), Investment Awareness.
\end{abstract}


INTERNATIONAL JOURNAL OF ACADEMIC RESEARCH IN BUSINESS AND SOCIAL SCIENCES

Vol. 10, No. 5, May, 2020, E-ISSN: 2222-6990 @ 2020 HRMARS

\section{Introduction}

Over the past several decades, educators in higher education have been involved in a paradigm shift from traditional face-to-face classroom teaching to experiential learning. The experiential learning theory proposed by Kolb was built upon the ideas of Lewin, Dewey and Piaget based on a 4-stage model integrating experience, concepts, observations and action (Kolb, 1984). Because of Kolb's ideas, experiential education, namely using educational simulation as a teaching strategy, has become increasingly popular in higher education. The learning process is scaffolding through acquiring of knowledge and skills from experience (Lim et al., 2018). It is a method of engaging learners in active learning through first-hand experience. Learners acquire skills, knowledge, and experience outside the traditional face-to-face classroom setting. Educators of higher education adopted various approaches in the experiential learning, such as educational simulation, problem-based learning, project-based learning, service-learning projects, field trips, field research, internships, and studies abroad.

According to Kreber, experiential learning is an effective way to foster higher-order learning skills among learners (Kreber, 2001). Experiential education encourages self-directed learning and critical thinking ability. Experiential learning provides the opportunity to learn from experience or learn by doing (Lewis \& Williams, 1994). Learners primarily become the beneficiary of experiential learning when they first immerse in an experience and then develop reflection about the experience to foster new skills, new attitudes, or new ways of thinking. It is also interesting to note that Kolb repeatedly emphasized that learning should not be sole judged based on its end goals; rather, learning should be viewed as a continuous process of inquiry, an interaction between the student and the environment (Kolb, 1984). This is what makes experiential learning so different from other traditional classroom learning styles.

Experiential learning, particularly through educational simulation, creates opportunities for learners to improve on various areas including functional knowledge, research skills, creativity and innovation skills, and information technology skills. Experiential learning through educational simulation provides opportunity for development of hard and soft skills requested by employers. The acquired skills prepare learners for future employment through ability of application of theories and concepts in the real-life situation.

This paper utilizes the Inter-Varsity Stock Challenge (IVSC) as a case study of how experiential learning through stock trading simulation increases investment awareness in the equity market. We believe that this approach of learning will enable students to bridge the gap between theoretical concepts and real-life financial investment decision. Several studies have measured the close relationship between the use of trading simulation and improved learning. Trading simulations are known to be effective in increasing participants' financial literacy (Santo \& Martelli, 2015).

Simulations are a preference over traditional teaching approach as the experience of simulation can increase long-term retention and memory of material when one experience the situation (Caniglia, 2019). The trading simulation is an effective pedagogical tool to stimulate selfmotivation to learn, increase financial literacy and improve learners' performance and satisfaction (Moffit et al., 2010). Learning through equity trading simulations effectively improves learners' interest and knowledge in investment and equity market. Trading simulation is recognized as a productive platform to move away from passive learner towards proactive learners in a dynamic learning cycle. Simulation has created an opportunity for participants to apply their subject- 
knowledge to participate in real-world, multi-faceted and challenging equity trading activities (Marriott et al., 2015).

Saenz and Cano research findings demonstrated that mistakes are part of participants' experiential learning process (Saenz \& Cano, 2009). Participants can select various investment decisions without any fear of real loss associated with mistakes. Dissatisfaction resulting from mistakes has been demonstrated as one of the core strength of educational simulation learning mechanism. Participants can derive experience through the consequences of their trading decisions that can come from a positive or negative simulation game outcome.

The active involvement of a tutor in the educational simulation is the core determinant of its effectiveness for enhancing the cognitive growth of participants (Marriott et al., 2015). Understanding the underlying principles of equity trading before embarking on the trading simulation activity is important to close the gap between the theory and real-life situations. Besides that, with the presence of a tutor in the form of an investment bank, students are able to learn from seasoned industry mentors that can provide greater insight than what the students would have achieved on their own.

\section{Problem Statement}

Jobstore Salary Report 2018-2019 reported that the average starting salary of fresh graduates with an Honors degree in Malaysia increased to RM2635, compared to RM2482 last year. Despite the moderate increase in salary, it is not proportionate to the steep rise of living cost of fresh graduates working in the metropolitan city. Thus, millennials are advised and encouraged to participate in investment, particularly in stock trading in order to survive the rat race environment in big cities. Many of them are aware of the need to invest in stock market in order to grow their net worth and optimize their hard- earned money. However, the traditional views and advice from their parents and elders on the risk of investment in the share market tend to hold them back from stock trading. The recent published results from the International Survey of Adult Financial Literacy Competencies by the Organization for Economic Cooperation and Development (OECD) showed that Malaysia was consistently ranked near the bottom of 30 OECD countries in terms of financial literacy (OECD, 2016). Initiatives to impart knowledge to the millennials in financial and stock market literacy need to be conducted particularly in the universities. As such, the IVSC was organized and carried out to boost and raise the millennials awareness of investing in stock market and to enhance their stock trading literacy. This effort tends to brainwash their reserved perceptions in stock trading via experiential and simulation learning while at university.

\section{Purpose of the Study}

The purpose of the study is to investigate the effectiveness of the IVSC to raise the millennials awareness of investing in stock market and enhance their stock trading literacy. This study also aimed to examine the correlation between the participants' perception of stock trading literacy and perception of effectiveness of workshops conducted during the IVSC to raise their stock trading literacy.

Four null hypotheses and their subsidiary null hypotheses were formulated to guide the research process.

$\mathrm{H}_{01}$ : There is no significant difference in the perception of initial awareness in stock trading literacy and stock literacy after the IVSC 
INTERNATIONAL JOURNAL OF ACADEMIC RESEARCH IN BUSINESS AND SOCIAL SCIENCES

Vol. 10, No. 5, May, 2020, E-ISSN: 2222-6990 @ 2020 HRMARS

$\mathrm{H}_{01 \mathrm{a}}$ : There is no significant difference in the perception of initial awareness in stock trading literacy (cognitive dimension) and stock literacy after the IVSC.

$\mathrm{H}_{01 b}$ : There is no significant difference in the perception of initial awareness in stock trading literacy (affective dimension) and stock literacy after the IVSC.

$\mathrm{H}_{01 c}$ : There is no significant difference in the perception of initial awareness in stock trading literacy (physical dimension) and stock literacy after the IVSC.

$\mathrm{H}_{02}$ : There is no significant difference in the perception of stock trading literacy between male and female participants after the IVSC.

$\mathrm{H}_{03}$ : There is no significant difference in the perception of stock trading literacy between business major and non-business major participants after the IVSC.

$\mathrm{H}_{04}$ : There is no correlation between the participants' perception of stock trading literacy and perception of effectiveness of workshops conducted during the IVSC.

$\mathrm{H}_{04 a}$ : There is no statistically significant relationship between perception on the effectiveness of stock trading workshops and perception of stock trading literacy in the cognitive dimension for participants in the IVSC.

$\mathrm{H}_{04 \mathrm{~b}}$ : There is no statistically significant relationship between perception on the effectiveness of stock trading workshops and perception of stock trading literacy in the affective dimension for participants in the IVSC.

$\mathrm{H}_{04 c}$ : There is no statistically significant relationship between perception on the effectiveness of stock trading workshops and perception of stock trading literacy in the physical dimension for participants in the IVSC.

\section{Research Framework}

This study adapts George Miller framework for assessing levels of competency by including the level of awareness prior to the simulation of stock trading (Miller, 1990). The original George Miller's Pyramid / Prism of Clinical Competence for assessing levels of clinical competence included the following:

- Knows [knows some knowledge]

- Knows how [knows how to apply that knowledge]

- Shows [shows how to apply that knowledge]

- Does [actually applies that knowledge in practice] 
As shown in Figure 1.

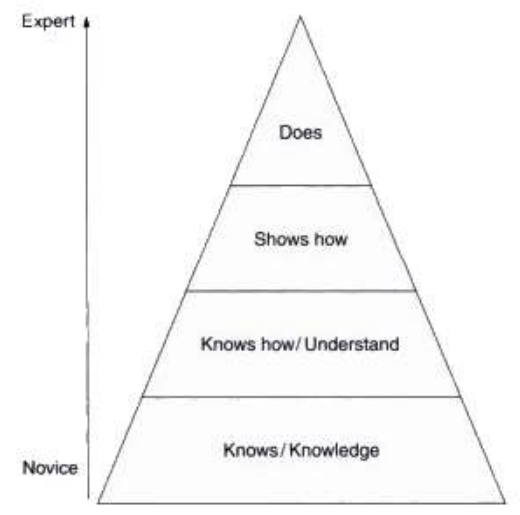

Figure 1: The Miller Pyramid and Prism

The proposed research framework for stock trading simulation in this study is adapted from The Miller Pyramid and Prism as shown in Figure 1. It shows the different levels in the perceptions of stock trading literacy with regards to the cognitive, affective and physical dimensions responded by the participants which occurs on the novice to expert continuum throughout the period of stock challenge / competition. It also includes an initial awareness level of stock trading which may underpin higher levels of stock trading literacy.

The initial awareness of participants is captured through a questionnaire prior to their registration to participate in the stock challenge. Participants were encouraged to attend a series of workshops throughout the stock challenge so as to gain stock trading literacy with regards to the three dimensions: cognitive, affective and physical. The perceptions of these three dimensions in stock trading literacy can then be captured in the questionnaire. A set of four null hypotheses stated in the purpose of study section were formulated from the proposed research framework to guide this research.

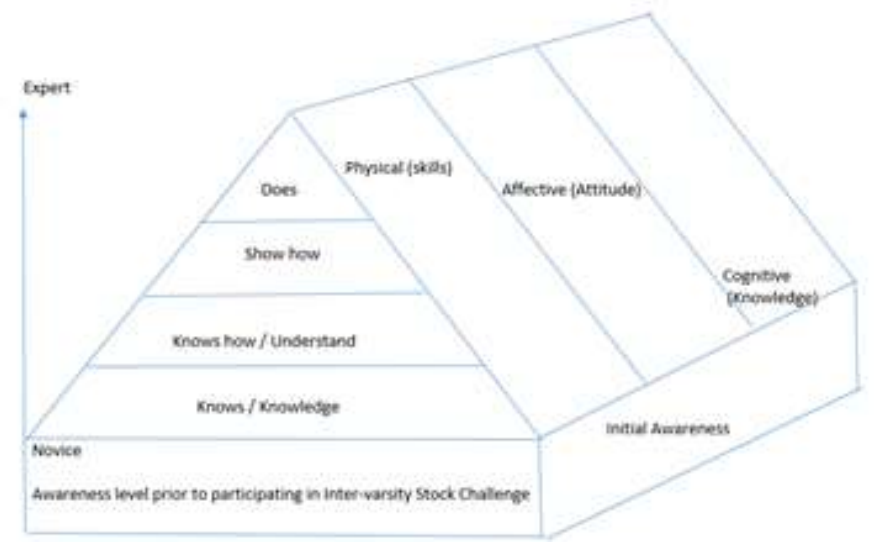

Figure 2: Proposed research framework for stock trading simulation adapted from The Miller Pyramid and Prism 
INTERNATIONAL JOURNAL OF ACADEMIC RESEARCH IN BUSINESS AND SOCIAL SCIENCES Vol. 10, No. 5, May, 2020, E-ISSN: 2222-6990 @ 2020 HRMARS

\section{Methodology}

This study investigates the effectiveness of experiential learning, specifically, in a stock trading simulation competition, to inculcate financial awareness amongst youths in Malaysia. The questionnaire was divided into two parts in order to study the learning experience of participants before and after participating in the equity trading simulation competition, namely the Inter-Varsity Stock Challenge (IVSC). This research also focuses on the cognitive, affective and physical dimensions of participants before and after participating in the IVSC. The comparison on the perception of stock trading literacy between gender and major of study of participants after the IVSC competition were performed. Besides that, this study also examine the correlation between perception on the effectiveness of stock trading workshops and perception of stock trading literacy for the participants in the IVSC.

\section{Inter-Varsity Stock Challenge (IVSC)}

The Inter-Varsity Stock Challenge was an industry engagement initiative by Taylor's University Industry Advisory Panel - N2N Connect Berhad and Taylor's American Degree Transfer Program. This Inter-Varsity competition was aimed to educate the next generation youths to be intelligent and informed investors in order to increase youth participation in the capital market. This IVSC was also a unique experiential learning strategy that encourages youths to learn more about stock trading, managing portfolios and analyzing market sentiments under the industry mentorship guidance of the broking houses.

The IVSC was the first-ever trading simulation where universities and broking houses were paired together to compete in the same game environment. The trading system was streaming live market data provided by N2N Connect Berhad - an integrated e-commerce securities trading solution provider. Trading was executed real-time and followed the local trading hours at Bursa Malaysia. This stock trading simulation competition demonstrated the industry and university engagement initiative that work together to educate students to achieve the highest amount of profit while competing amongst other Uni-Broker teams.

This interactive stock trading competition was opened to university/college and high school students to trade virtually for a period of 3 months (2nd May - 28th July 2019). This competition was a team challenge, comprising of 1-4 members in a team. The teams were put to the challenge of achieving the highest returns from real time investments with a virtual initial investment capital of RM100,000 per team. Apart from demonstrating the ability to maximize investment returns, they were also required to demonstrate a sound understanding of investment principles and strategies to the panel of judges comprising of industry leaders in the financial markets during the finals. The judging criteria were $70 \%$ on profit made based on portfolio value and $30 \%$ on quality of trading strategy presented during the finals.

The game mechanics and platform introduction consist of the features of trading system, trading rules, trial sessions, research and mentor chats was executed prior to the stock trading competition. There were 6 workshop series led by the equity researchers from industry mentorship on a fortnightly basis to enhance the effectiveness of cognitive growth among participants. The active involvement of industry mentorship throughout the workshops is the core determinant to close the gap between the theory and real-life situations before participants embark on the stock trading simulation. The workshop series introduced the investment strategies on the technical analysis and value investing to generate interest among young people and build their confidence in becoming 
savvy, knowledgeable capital market investors. Beside workshops, the trading system had an inbuilt live chat function to provide daily education, research and insights of capital market. Participants were able to utilize the live chat function to communicate with mentors to get their guidance and feedback throughout the competition. One of the unique feature that was not executed in previous research studies was that the participants in the IVSC were able to learn from the industry experts. The active involvement of industry mentorship is the core determinant to close the gap between the theory and real-life situations before participants embark on the trading simulation activity.

\section{Participants}

A total of 787 teams from 3 universities were paired with 3 broking houses competing in the equity trading simulation competition. Total of 300 teams were from Taylor's, and the remaining teams from UTAR and MMU. This study focuses on 44 teams from Taylor's University that were ranked at top 100 on the IVSC. A total of 70 participants from 29 teams responded to the online questionnaire. The respondents are from various educational background studying in various programs from universities, colleges and high schools.

\section{Data Analysis}

The data obtained from the questionnaires completed by 70 participants of the IVSC were then entered, tabulated and analyzed using Statistical Package for Social Science (SPSS) version 20. Several statistical procedures were used on the data collected.

All items are responded to on a Likert scale of $1-5$, where $5=$ Strongly Agree and $1=$ Strongly Disagree.

A reliability analysis was carried out on the perceived task values scale comprising 2 items and 13 items for the cognitive construct before and after, respectively; 3 items and 4 items for the affective construct before and after, respectively; 4 items and 6 items for the physical construct before and after, respectively.

Cronbach's alpha showed the questionnaire to reach acceptable reliability, $\alpha$ between 0.71 and 0.96 which indicates that the measures were valid as the reliability coefficients obtained for all 3 dimensions were higher than the recommended level of 0.70 . All items appeared to be worthy of retention.

Paired samples t-test was used to compare the perception of stock trading literacy before and after the IVSC. An independent samples t-test was then used to compare the perception of stock trading literacy between male and female participants as well as between business and non-business major participant. Finally, Pearson moment correlation test was used to determine if there was a correlation between the participants' perception of stock trading literacy and perception of effectiveness of workshops conducted during the IVSC.

\section{Results and Findings}

The hypotheses which were formulated to guide this research were then tested.

\section{Testing of Null Hypothesis $\mathrm{H}_{01}$}

Paired samples t-test was conducted to compare the perception of initial awareness in stock trading literacy and stock trading literacy after the IVSC. 
INTERNATIONAL JOURNAL OF ACADEMIC RESEARCH IN BUSINESS AND SOCIAL SCIENCES Vol. 10, No. 5, May, 2020, E-ISSN: 2222-6990 @ 2020 HRMARS

As indicated in the paired samples t-test statistics shown in Table 1, the p-value for each pair is less than 0.05 , thus the null hypothesis $\mathrm{H}_{01}$ and its associated subsidiary null hypotheses are rejected in favor of the alternative hypotheses. The following results are reported based on the paired samples t-test statistics.

Table 1: Paired Samples t-test for awareness in stock trading literacy before and after the IVSC

\begin{tabular}{|c|c|c|c|c|c|}
\hline \multicolumn{6}{|c|}{ Palred Samples Statilestlos } \\
\hline & & Moan & $\mathrm{N}$ & Sid. Daiation & $\begin{array}{l}\text { sid. Emor } \\
\text { Moun }\end{array}$ \\
\hline \multirow[t]{2}{*}{ Palr 1} & StockTradhof waronoss & 3.0611 & 70 & 5181 & .08030 \\
\hline & StockTradhollibray & 3.9511 & 70 & .78853 & .00425 \\
\hline \multirow[t]{2}{*}{ Palr 2} & Avecogg & 3.4857 & 70 & 1.06312 & .12707 \\
\hline & AveCogA & 3.9214 & $7 p$ & .7023 & .09553 \\
\hline \multirow[t]{2}{*}{ Palr 3} & AvoAf & 3.2619 & 70 & 1.09588 & .13098 \\
\hline & AvoAHA & 4.0762 & 70 & 80091 & .09573 \\
\hline \multirow[t]{2}{*}{ Palr 4} & Avopty & 2.4357 & 70 & .74050 & .08851 \\
\hline & Avopthy & 3.7857 & 70 & 80105 & .10650 \\
\hline
\end{tabular}

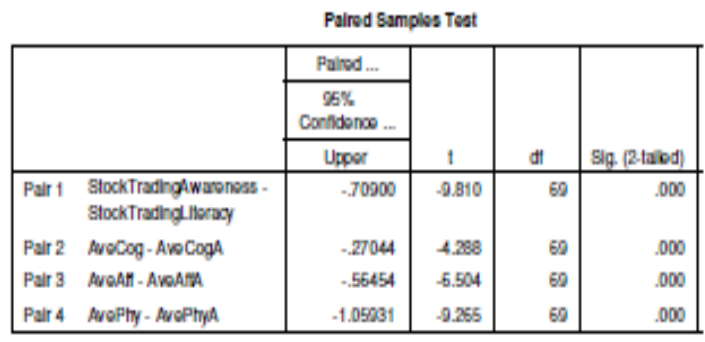

$\mathrm{H}_{1}$ : there is a significant difference in the perception of stock trading literacy before $(M=3.06$, $S D=0.67)$ and stock trading literacy after the IVSC (M=3.95, SD=0.79); $t(69)=9.81, p=0.000$.

$\mathrm{H}_{1 \mathrm{a}}$ : there is a significant difference in the perception of stock trading literacy (cognitive dimension) before $(M=3.49, S D=1.06)$ and after the IVSC $(M=3.99, S D=0.80) ; t(69)=4.29, p=0.000$.

$\mathrm{H}_{1 \mathrm{~b}}$ : there is a significant difference in the perception of stock trading literacy (affective dimension) before $(M=3.26, S D=1.10)$ and after the IVSC $(M=4.08, S D=0.80) ; t(69)=6.50, p=0.000$.

$\mathrm{H}_{1 \mathrm{c}}$ : there is a significant difference in the perception of stock trading literacy (physical dimension) before $(M=2.44, S D=0.74)$ and after the IVSC $(M=3.79, S D=0.89) ; t(69)=9.27, p=0.000$.

These results suggest that the IVSC does have an impact on Stock trading literacy. Specifically, our results suggest that when participants underwent the transaction activities during the period of competition, their level of perception in stock trading literacy in the cognitive dimension, affective dimension and physical dimension increased. Thus, this indicates that learning took place during the IVSC.

\section{Testing of Null Hypothesis $\mathrm{H}_{02}$}

An independent samples t-test was performed on the perception of stock trading literacy between the male and female participants after the IVSC. As indicated in the independent samples test statistics shown in Table 2 , the $p$-value is more than 0.05 , thus, the null hypothesis cannot be rejected. The following results are reported based on the independent samples t-test statistics.

$\mathrm{H}_{02}$ : There is no significant difference in the perception of stock trading literacy after the IVSC between male participants $(M=3.92, S D=0.77)$ and female participants $(M=4.02, S D=0.85)$; $t(68)=-$ $0.47, p=0.64$.

Table 2: Independent Samples t-test between male and female on stock trading literacy before and after the IVSC 
INTERNATIONAL JOURNAL OF ACADEMIC RESEARCH IN BUSINESS AND SOCIAL SCIENCES

Vol. 10, No. 5, May, 2020, E-ISSN: 2222-6990 @ 2020 HRMARS

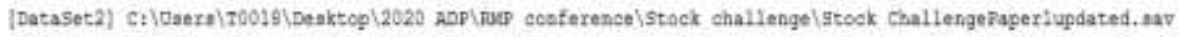

\begin{tabular}{|c|c|c|c|c|c|}
\hline \multicolumn{6}{|c|}{ alistics } \\
\hline & Gendet & N & Nam & Sut Denation & $\begin{array}{l}\text { Stit Eitor } \\
\text { Wean }\end{array}$ \\
\hline \multirow[t]{2}{*}{ Stocifradioghiwaraness } & Wae & 48 & 30775 & 67735 & 09632 \\
\hline & Femais & 22 & 30253 & 69564 & 14895 \\
\hline \multirow[t]{2}{*}{ StosaTradingLiteracy } & Wate & 48 & 39207 & 76641 & 11052 \\
\hline & Fenale & 22 & 40174 & 84950 & 18112 \\
\hline \multirow[t]{2}{*}{ Workshoperectieness } & Mata & 18 & $3985 t$ & $765 \pi 7$ & 11053 \\
\hline & Fermate & 22 & 40594 & 32674 & 17620 \\
\hline
\end{tabular}

\begin{tabular}{|c|c|c|c|c|c|c|c|c|c|c|}
\hline \multicolumn{11}{|c|}{ Insependent Sameles Test } \\
\hline & & \multicolumn{2}{|c|}{$\begin{array}{l}\text { Leena's Fest for Equalty of } \\
\text { Yariances }\end{array}$} & \multicolumn{7}{|c|}{ Fest tor Equalit or maans } \\
\hline & & \multirow[b]{2}{*}{$F$} & \multirow[b]{2}{*}{ Sig. } & \multirow[b]{2}{*}{$t$} & \multirow[b]{2}{*}{ d } & \multirow[b]{2}{*}{512 (2-taled) } & \multirow{2}{*}{$\begin{array}{l}\text { Uvan } \\
\text { oifrertecs }\end{array}$} & \multirow{2}{*}{$\begin{array}{l}\text { 5it Ence } \\
\text { Onterente }\end{array}$} & \multicolumn{2}{|c|}{$\begin{array}{l}\text { 55\$ Corfadente interval of the } \\
\text { Dherante. }\end{array}$} \\
\hline & & & & & & & & & LOMES & Uppat \\
\hline \multirow[t]{2}{*}{ Stocktradinghtwareness } & $\begin{array}{l}\text { Equér variancess } \\
\text { assumed }\end{array}$ & 698 & $76 \mathrm{~B}$ & 300 & $\overline{6}$ & 365 & 95229 & 17412 & -23515 & 39974 \\
\hline & $\begin{array}{l}\text { Equal variancas not } \\
\text { assumed }\end{array}$ & & & 295 & 39316 & 369 & 05229 & .17898 & .30539 & 40998 \\
\hline \multirow[t]{2}{*}{ StoditradivgLteracy } & $\begin{array}{l}\text { Equal vamances } \\
\text { assumed }\end{array}$ & 1.690 & 226 & -474 & 69 & 637 & -09671 & 20417 & -50412 & 31071 \\
\hline & $\begin{array}{l}\text { Equa variances not } \\
\text { astumed }\end{array}$ & & & -456 & 37273 & 651 & -09521 & 21223 & -52651 & 33320 \\
\hline \multirow[t]{2}{*}{ WooshopEre:fieness } & $\begin{array}{l}\text { Equa variancss } \\
\text { assumed }\end{array}$ & 1.327 & 253 & .363 & 68 & 310 & .07332 & 20214 & .47669 & 33003 \\
\hline & $\begin{array}{l}\text { Equar variantes not } \\
\text { assumed }\end{array}$ & & & -352 & 38.128 & 726 & -07332 & 20005 & -49445 & 36781 \\
\hline
\end{tabular}

These results suggest that after undergoing the stock trading transaction activities specified in the IVSC, there appeared to be no significant difference in the perception of stock trading literacy level for both groups of participants. This implied that similar learning experience took place for male participants and female participants after participating in the IVSC.

\section{Testing of Null Hypothesis $\mathrm{H}_{03}$}

An independent samples t-test was performed on the perception of stock trading literacy between business major and non-business major participants after the IVSC. As indicated in the independent samples test statistics shown in Table 3, the p-value is less than 0.05 , thus, the null hypothesis is rejected. The following results are reported based on the independent samples t-test statistics.

$\mathrm{H}_{3}$ : There is a significant difference in the perception of stock trading literacy after the IVSC between business major participants $(M=4.25, S D=0.62)$ and non-business major participants $(M=3.63$, $\mathrm{SD}=0.78) ; \mathrm{t}(63)=3.57, \mathrm{p}=0.001$.

These results suggest that after undergoing stock trading transaction activities specified in the IVSC, there appeared to be a significant difference in the perception of stock trading literacy level between the two groups of participants. This implied that business major participants have gained higher stock trading literacy as compared to non-business major participants after participating the IVSC. 
INTERNATIONAL JOURNAL OF ACADEMIC RESEARCH IN BUSINESS AND SOCIAL SCIENCES Vol. 10, No. 5, May, 2020, E-ISSN: 2222-6990 ㄷ 2020 HRMARS

Table 3: Independent Samples t-test between business major and non-business major on stock trading literacy before and after the IVSC

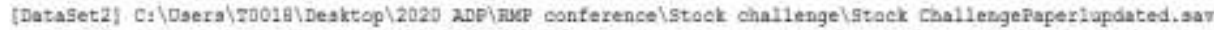

\begin{tabular}{|c|c|c|c|c|c|}
\hline & Meior & $\mathrm{N}$ & Mean & Stad Deristion & $\begin{array}{l}\text { Stt Entrut } \\
\text { Mean }\end{array}$ \\
\hline \multirow[t]{2}{*}{ StokkTradingawatensss } & Fusiness & 40 & 30881 & 59303 & 10959 \\
\hline & Non-Gusiness & 25 & 31122 & .66761 & 13352 \\
\hline \multirow[t]{2}{*}{ StotkTradioglogracy } & Fusinass & 40 & 4.2544 & 61608 & $0974 !$ \\
\hline & Non-Business & 25 & 3.6334 & 77793 & 15558 \\
\hline \multirow[t]{2}{*}{ Woikshoserectivens:ss } & Busingss & 40 & 4.2788 & 64129 & 10110 \\
\hline & NunBusiness & 25 & $3.7 m$ & 70238 & 14048 \\
\hline
\end{tabular}

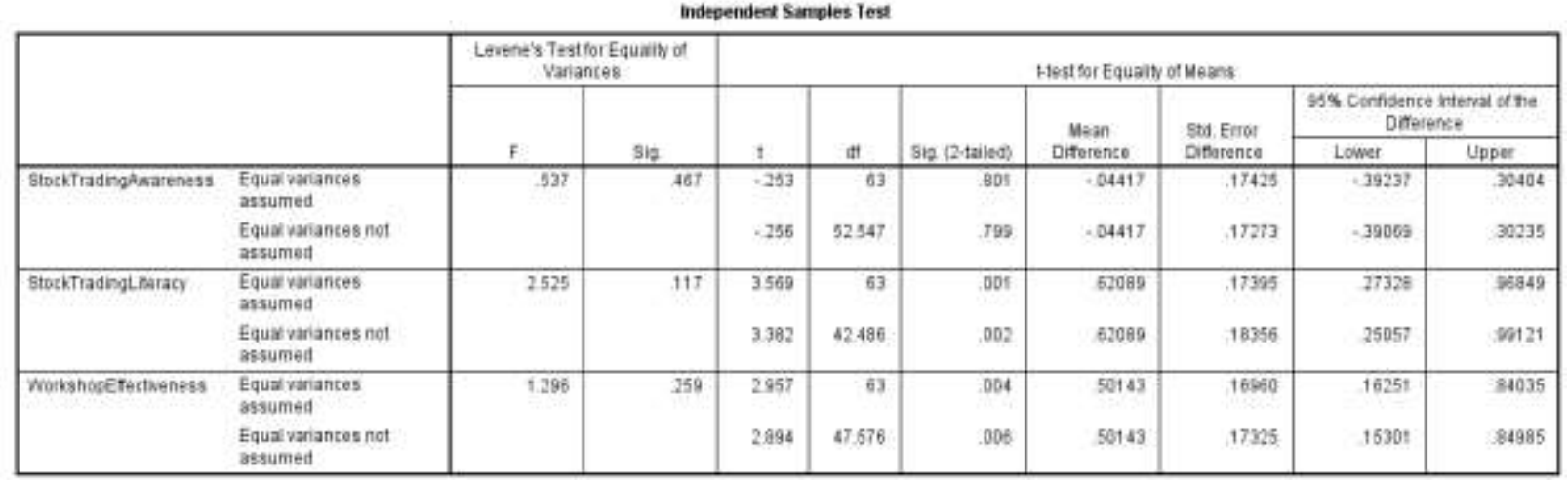

Testing of Null Hypothesis $\mathrm{H}_{04}$

A Pearson product-moment correlation coefficient was computed to assess the relationship between perception on the effectiveness of stock trading workshops and perception of stock trading literacy and its respective dimensions for the participants in the IVSC. The statistical analysis on Table 4 revealed that there is a significant strong correlation between the perception on the effectiveness of stock trading workshops and perception of stock trading literacy $(r=0.896, n=70, p<0.05$, twotailed). Thus, null hypothesis $\mathrm{H}_{04}$ was rejected in favor of its alternative hypothesis. It follows that there is a statistically significant, positively strong correlation between the perception on the effectiveness of stock trading workshops and perception of stock trading literacy. This statistical analysis revealed that conducting a series of workshops on stock trading will effectively increase the awareness and literacy of participants while taking part in the IVSC.

\section{Testing of null hypothesis $\mathrm{H}_{04 a}$}

$\mathrm{H}_{04 a}$ : There is no statistically significant relationship between perception on the effectiveness of stock trading workshops and perception of stock trading literacy in the cognitive dimension for participants in the IVSC.

For the cognitive dimension, statistical analysis revealed that there is a significant strong correlation between the perception on the effectiveness of stock trading workshops and perception of stock trading literacy $\left(r=0.904, n=70, p<0.05\right.$, two-tailed). Thus, null hypothesis $\mathrm{H}_{04 a}$ was rejected in favor of its alternative hypothesis. It follows that there is a statistically significant, positively strong correlation between the perception on the effectiveness of stock trading workshops and perception of stock trading literacy in the cognitive dimension. 
INTERNATIONAL JOURNAL OF ACADEMIC RESEARCH IN BUSINESS AND SOCIAL SCIENCES

Vol. 10, No. 5, May, 2020, E-ISSN: 2222-6990 ㄷ 2020 HRMARS

\section{Testing of null hypothesis $\mathrm{H}_{04 \mathrm{~b}}$}

$\mathrm{H}_{04 \mathrm{~b}}$ : There is no statistically significant relationship between perception on the effectiveness of stock trading workshops and perception of stock trading literacy in the affective dimension for participants in the IVSC.

For the affective dimension, statistical analysis revealed that there is a significant strong correlation between the perception on the effectiveness of stock trading workshops and perception of stock trading literacy $\left(r=0.849, n=70, p<0.05\right.$, two-tailed). Thus, null hypothesis $\mathrm{H}_{04 c}$ was rejected in favor of its alternative hypothesis. It follows that there is a statistically significant, positively strong correlation between the perception on the effectiveness of stock trading workshops and perception of stock trading literacy in the physical dimension.

\section{Testing of null hypothesis $\mathrm{H}_{04 c}$}

$\mathrm{H}_{04 \mathrm{c}}$ : There is no statistically significant relationship between perception on the effectiveness of stock trading workshops and perception of stock trading literacy in the physical dimension for participants in the IVSC.

For the physical dimension, statistical analysis revealed that there is a significant strong correlation between the perception on the effectiveness of stock trading workshops and perception of stock trading literacy $\left(r=0.804, n=70, p<0.05\right.$, two-tailed). Thus, null hypothesis $\mathrm{H}_{04 \mathrm{~b}}$ was rejected in favor of its alternative hypothesis. It follows that there is a statistically significant, positively strong correlation between the perception on the effectiveness of stock trading workshops and perception of stock trading literacy in the affective dimension.

Since all the subsidiary null hypotheses in the primary null hypothesis $\mathrm{H}_{04}$ were rejected in favor of the alternative subsidiary hypotheses, overall there is statistically strong positive correlation between the perception on the effectiveness of stock trading workshops and perception of stock trading literacy with regards to cognitive, affective, physical dimensions. This statistical analysis revealed that active involvement of stock trading workshop series is the core determinant of its effectiveness for enhancing the cognitive, affective and physical growth of participants. 
INTERNATIONAL JOURNAL OF ACADEMIC RESEARCH IN BUSINESS AND SOCIAL SCIENCES Vol. 10, No. 5, May, 2020, E-ISSN: 2222-6990 ㄷ 2020 HRMARS

Table 4: Pearson's Product-Moment Correlation coefficients between perception on the effectiveness of stock trading workshops and perception of stock trading literacy

\section{$\Rightarrow$ Correlations}

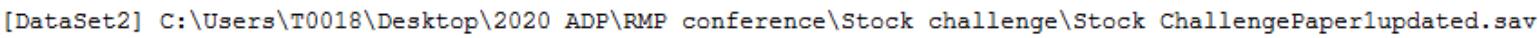

\begin{tabular}{|c|c|c|c|c|c|c|}
\hline \multicolumn{7}{|c|}{ Correlations } \\
\hline & & $\begin{array}{c}\text { StockTrading } \\
\text { Literacy }\end{array}$ & AveCogA & AveAffA & AvePhyA & $\begin{array}{c}\text { WorkshopEffe } \\
\text { ctiveness }\end{array}$ \\
\hline \multirow[t]{3}{*}{ StockTradingLiteracy } & Pearson Correlation & 1 & $.954^{\prime \prime}$ & $.967^{\prime \prime \prime}$ & $.930^{\prime \prime}$ & $.896 "$ \\
\hline & Sig. (2-tailed) & & .000 & .000 & .000 & .000 \\
\hline & $\mathrm{N}$ & 70 & 70 & 70 & 70 & 70 \\
\hline \multirow[t]{3}{*}{ AveCogA } & Pearson Correlation & $.954^{\prime \prime \prime}$ & 1 & $.929^{\prime \prime \prime}$ & $.801^{\prime \prime}$ & $.903^{\prime \prime}$ \\
\hline & Sig. (2-tailed) & .000 & & .000 & .000 & .000 \\
\hline & $\mathrm{N}$ & 70 & 70 & 70 & 70 & 70 \\
\hline \multirow[t]{3}{*}{ AveAffA } & Pearson Correlation & $.967^{111}$ & $.929^{\mathrm{N \prime}}$ & 1 & $.836^{\prime \prime}$ & $.849^{11}$ \\
\hline & Sig. (2-tailed) & .000 & .000 & & .000 & .000 \\
\hline & $\mathrm{N}$ & 70 & 70 & 70 & 70 & 70 \\
\hline \multirow[t]{3}{*}{ AvePhyA } & Pearson Correlation & $.930 "$ & $.801^{m}$ & $.836^{\prime \prime}$ & 1 & $.804^{\prime \prime}$ \\
\hline & Sig. (2-tailed) & .000 & .000 & .000 & & .000 \\
\hline & $\mathrm{N}$ & 70 & 70 & 70 & 70 & 70 \\
\hline \multirow[t]{3}{*}{ WorkshopEffectiveness } & Pearson Correlation & $.896^{\pi / 1}$ & $.903^{\mathrm{Nm}}$ & $.849^{110}$ & $.804^{n}$ & 1 \\
\hline & Sig. (2-tailed) & .000 & .000 & .000 & .000 & \\
\hline & $\mathrm{N}$ & 70 & 70 & 70 & 70 & 70 \\
\hline
\end{tabular}

**. Correlation is significant at the 0.01 level (2-tailed).

\section{Discussion}

The statistical analysis revealed that there was a significant difference in the perception of initial awareness in stock trading literacy and stock trading literacy after the IVSC with regards to the cognitive, affective and physical dimensions. The results revealed that the IVSC has met its objective to raise financial literacy among the youth. Business major participants have gained relatively higher stock trading literacy as compared to non-business major participants after participating the IVSC. However, there were no significant difference in the perception of stock trading literacy between gender of participants after the IVSC. This indicated that all participants regardless of their gender have similar learning experience with regards to stock trading throughout the IVSC.

The results also revealed that there was a strong statistical positive correlation between perception on the effectiveness of stock trading workshops and perception of stock trading literacy with regards to the cognitive, affective and physical dimensions of the participants in the IVSC. This result reaffirmed that IVSC was a unique experiential learning strategy that encourages youth to learn more about stock trading under the industry mentorship guidance of the broking houses.

\section{Conclusion}

The IVSC is a good platform to raise awareness of stock market investing and promote financial literacy amongst millennials who are the next generation of investors. This IVSC was a unique experiential learning strategy that encourages youths to learn more about stock trading, managing portfolios and analyzing market sentiments under the industry mentorship guidance of the broking houses. The active involvement of industry mentorship throughout the workshops is the core determinant to close the gap between the theory and real-life situations before participants embarking on the stock trading simulation. 
INTERNATIONAL JOURNAL OF ACADEMIC RESEARCH IN BUSINESS AND SOCIAL SCIENCES Vol. 10, No. 5, May, 2020, E-ISSN: 2222-6990 @ 2020 HRMARS

There is a need to organize stock trading competitions in university with collaborations from market capital players as a critical enabler so as to develop a sustainable and vibrant capital market. The stock trading competition, particularly the IVSC has created the right type of conversation to generate interest among young people and build their confidence in becoming savvy, knowledgeable capital market investors.

\section{Suggestions for Future Studies}

This study has revealed that the IVSC as an industry-led initiative can be recognized as an effective platform to raise awareness on stock market investing and promote financial literacy amongst the youths. However, further investigation on the effectiveness of stock trading simulation activity to prepare learners for future employment through ability of application of theories and concepts in the real-life situations is recommended. The study pertaining to advantages of the experiential learning through stock trading simulation in other areas such as life-long learning, intrapersonal and interpersonal growth of participants can be further explored in future studies.

\section{References}

Akeem, S. A. (2010). Effect of Experiential Earning in Business Statistics, Journal of Education for Business, 95-98.

Bedawy, R. E. (2017). Experiential Learning for Supporting Learning Effectiveness in Business Education: A Case Study from Egypt, International Journal of Business and Management; 12( 5), 159-176.

Blažič, A. J., \& Novak, F. (2015). Challenges of Business Simulation Games - A New Approach of Teaching Business, http://dx.doi.org/10.5772/61242, Chapter 10, 227-259.

Caniglia, J. (2019). Simulation as a Teaching Strategy, Kent State University Center for Teaching and Learning.

Herz, B., \& Merz, W. (1998). Experiential Learning and the Effectiveness of Economic Simulation Games, Simulation and Gaming, 29(2), 238-250.

Kolb, D. A. (1984). Experiential learning: experience as the source of learning and development, Englewood Cliffs, NJ: Prentice Hall.

Kreber, C. (2001). Learning experientially through case studies? A conceptual analysis, Teaching in Higher Education, 6, 217-228.

Lewis, L. H., \& Williams, C. J. (1994). In Jackson, L. \& Caffarella, R.S. (Eds.). Experiential Learning: A New Approach, San Francisco: Jossey-Bass, 5-16

Lim, Y. P., Loh, K. H., \& Chiew, G. E. (2018). Investigating students' Reflection of Learning experience and perception on achievement of Graduate capability in experiential Learning through an interdisciplinary project, Advances in Natural and Applied Sciences, 12(7), 26-32.

Loh, K. H., Lim, Y. P., Chiew, G. E., \& Low, K. R. (2018). Adopting Authentic Problem-based Learning (APBL) to Enhance Self-efficacy of Learning and Perceived Digital Literacy Skills of University Students, Journal of Social Science and Humanities, 1 (1), 25-32.

Malaysia National Strategy for Financial Literacy. (2019-2023), Financial Education Network: Empowering Financial Freedom, https://www.fenetwork.my/wp-content/uploads/2019/07/National-Strategy-English.pdf 
INTERNATIONAL JOURNAL OF ACADEMIC RESEARCH IN BUSINESS AND SOCIAL SCIENCES

Vol. 10, No. 5, May, 2020, E-ISSN: 2222-6990 @ 2020 HRMARS

Marriott, P., Tan, S. M., \& Marriott, N. (2015). Experiential Learning - A Case Study of the Use of Computerised Stock Market Trading Simulation in Finance Education, RMIT Accounting Educators' Conference 2014, 24(6), 480-497.

Miller, G. E. (1990). The assessment of clinical skills/competence/performance. Acad Med, Sep, 65(9 Suppl), S63-S67.

Moffit, T., Stull, C., \& McKinney, H. (2010) Learning Through Equity Trading Simulation, American Journal of Business Education, 3(2), 65-73.

Mupinga, D. M., \& Caniglia, J. (2019). Students' Reflections on the Benefits of a Financial Simulation Through "Thank You Notes", 202-209.

Organisation for Economic Co-operation and Development. (2016). OECD/INFE International Survey of Adult Financial Literacy Competencies, OECD, Paris, www.oecd.org/finance/OECD-INFEInternational-Survey-of-Adult-Financial-Literacy-Competencies.pdf

Parcell, J. L., \& Franken, J. R. V. (2009). Teaching Options and Futures Trading Through Experiential Learning, NACTA Journal, 53(3), 11-16.

Saenz, M. J., \& Cano, J. L. (2009). Experiential learning through simulation games: An empirical study, International Journal of Engineering Education, 25(2), 296-307.

Santo, A. D., \& Martelli, D. (2015). Increasing Financial Literacy through Simulations: The Case of the CFA Society Italy Fund Management Challenge, Journal of Financial Management Markets and Institutions, 3(1), 69-100. 